\title{
Rola funkcji compliance w zarządzaniu ryzykiem braku zgodności w zakładzie ubezpieczeń
}

Zasadniczym celem niniejszego artykułu jest próba przedstawienia roli i znaczenia funkcji compliance w procesie zarzqdzania ryzykiem braku zgodności w zakładzie ubezpieczeń w ramach funkcjonowania i organizacji tej jednostki w strukturach zakładu ubezpieczeń. Metodq, która służy realizacji tego celu, jest w opinii autora przede wszystkim charakterystyka i ocena aktualnego środowiska regulacyjnego w kontekście jego wpływu na organizację i funkcjonowanie jednostki ds. zgodności w zakładzie ubezpieczeń. Rozważania poświęcone procesowi zarzadzania ryzykiem braku zgodności zostały przedstawione z uwzględnieniem rozwiq̨zań prawnych obowiq̨ujacych w tym zakresie w bankach.

Słowa kluczowe: compliance, funkcja zgodności z przepisami, ryzyko braku zgodności, zgodność, regulacje.

\section{Wprowadzenie}

Systematyczny wzrost wymogów prawnych i nadzorczych wobec instytucji finansowych, w tym zakładów ubezpieczeń, skutkuje proporcjonalnym wzrostem ekspozycji na ryzyko poniesienia przez te podmioty strat finansowych i niefinansowych w związku z naruszeniem określonych obowiązków. Ryzyko braku zgodności w instytucjach finansowych należy definiować jako ryzyko nieprzestrzegania przepisów prawa, regulacji wewnętrznych oraz przyjętych standardów postępowania ${ }^{1}$. Powyższa definicja została przyjęta przez Komisję Nadzoru Finansowego w uchwale nr 258/2011 z dnia 4 października 2011 roku w odniesieniu do sektora bankowego². Jednak wydaje

1. Ł. Cichy, Funkcja compliance w bankach, CEDUR, Komisja Nadzoru Finansowego, Warszawa 2015, s. ?-8.

2. Uchwała Komisji Nadzoru Finansowego nr 258/2011 z dnia 4 października 2011 r. w sprawie szczegółowych zasad funkcjonowania systemu zarządzania ryzykiem i systemu kontroli wewnętrznej oraz szczegółowych warunków szacowania przez banki kapitału wewnętrznego i dokonywania przeglądów procesu szacowania i utrzymywania kapitału wewnętrznego oraz zasad ustalania polityki zmiennych składników wynagrodzeń osób zajmujących stanowiska kierownicze w banku. 
się ona mieć charakter uniwersalny względem innych instytucji finansowych. Ziszczenie się ryzyka braku zgodności będzie skutkowało poniesieniem przez podmiot dopuszczający się naruszenia sankcji finansowych, a także możliwością utraty reputacji oraz wiarygodności.

Prowadzenie działalności przez zakład ubezpieczeń zgodnie obowiązującym prawem, regulacjami wewnętrznymi oraz oczekiwaniami nadzorczymi niewątpliwie stanowi element bezpiecznego, stabilnego oraz ostrożnego zarządzania zakładem ubezpieczeń. Sama funkcja zgodności z przepisami w zakładzie ubezpieczeń jest kwalifikowana przez prawodawców jako funkcja kluczowa, będąca częścią systemu zarzạdzania zakładem ubezpieczeń. Nie ulega wạtpliwości, że wraz ze wzrostem regulacji rola i znaczenie funkcji zgodności na rynku ubezpieczeniowym będzie systematycznie wzrastać, tak jak ma to miejsce w bardziej rozwiniętych sferach rynku finansowego.

Celem niniejszego artykułu jest próba określenia znaczenia funkcji compliance w procesie zarządzania ryzykiem braku zgodności w zakładzie ubezpieczeń poprzez pryzmat funkcjonowania i organizacji tej jednostki w strukturach zakładu ubezpieczeń. Praca została sporządzona na podstawie literatury przedmiotu oraz w świetle krajowych i europejskich regulacji prawnych odnoszących się do funkcji compliance w zakładzie ubezpieczeń. Uwzględnia również oczekiwania nadzorcze kierowane do instytucji finansowych w powyższym zakresie.

\section{1. Środowisko regulacyjne w obrębie funkcji compliance w zakładach ubezpieczeń}

Funkcja compliance w polskim prawie ubezpieczeniowym została wyraźnie wyodrębniona i ukształtowana w strukturze zakładów ubezpieczeń pod wpływem uchwalenia przez Parlament Europejski Dyrektywy 2009/138/WE z dnia 25 listopada 2009 roku w sprawie podejmowania i prowadzenia działalności ubezpieczeniowej i reasekuracyjnej (Solvency II; Dz. U. UE L z dnia 17 grudnia 2009 roku $)^{3}$. Okres ten z pewnością był przełomowy dla rozwoju funkcji compliance w zakładach ubezpieczeń. W czasie poprzedzającym uchwalenie Dyrektywy Solvency II, funkcja compliance w praktyce polskiego rynku ubezpieczeniowego nie była w pełni ukształtowana i wyodrębniona. Zadania funkcji compliance były wtedy realizowane przez komórkę ds. prawnych, komórkę ryzyka lub komórkę audytu wewnętrznego ${ }^{4}$. Okoliczność ta została również dostrzeżona przez prawodawcę europejskiego, który w motywach ( nr 30) do Dyrektywy Solvency // wyraźnie wskazał, że system zarządzania zakładem ubezpieczeń składa się z funkcji zarządzania ryzykiem, funkcji audytu wewnętrznego, funkcji aktuarialnej oraz funkcji zgodności z przepisami. Zdaniem prawodawcy europejskiego skuteczny system zarządzania ma zasadnicze znaczenie dla odpowiedniego zarządzania zakładami ubezpieczeń ${ }^{5}$.

Wyodrębnienie i ukształtowanie funkcji compliance w zakładach ubezpieczeń nastapiło w wyniku wejścia w życie Dyrektywy Solvency II. Jej ostateczny kształt z perspektywy zakładów

3. Dyrektywa Parlamentu Europejskiego i Rady 2009/138/WE z dnia 25 listopada 2009 r. w sprawie podejmowania i prowadzenia działalności ubezpieczeniowej i reasekuracyjnej (Solvency II], Dz. U.UE L z dnia 17 grudnia $2009 \mathrm{r}$.

4. B. Mrozowska-Bartkiewicz, A. Wnęk, Funkcja compliance w zakładzie ubezpieczeń, „Prawo Asekuracyjne” 2016, nr 1, s. 71.

5. Preambuła do Dyrektywy Solvency II. 
ubezpieczeń prowadzących działalność w Polsce został nadany przez ustawę z dnia 11 września 2015 roku o działalności ubezpieczeniowej i reasekuracyjnej (dalej: u.dz.u.r.] ${ }^{6}$, która implementowała do polskiego porzadku prawnego Dyrektywę Solvency II. Powyższe regulacje wprowadziły obowiązek ustanowienia funkcji compliance w zakładach ubezpieczeń od 1 stycznia 2016 roku.

Rola jednostki ds. zgodności z przepisami została określona w art. 64 ust. 2 u.dz.u.r. Zgodnie z tym przepisem funkcja zgodności z przepisami obejmuje:

- doradzanie zarządowi i radzie nadzorczej zakładu w zakresie zgodności wykonywania działalności ubezpieczeniowej lub reasekuracyjnej z przepisami prawa;

- ocenę możliwego wpływu wszelkich zmian stanu prawnego na operacje zakładu;

- określenie i ocenę ryzyka związanego z nieprzestrzeganiem przepisów prawa, regulacji wewnętrznych oraz przyjętych przez zakład standardów postępowania.

Jednocześnie, funkcja compliance została zakwalifikowana jako element systemu zarzadzania zakładem ubezpieczeń, poza funkcją zarządzania ryzykiem, funkcją audytu wewnętrznego oraz funkcją aktuarialną, których łącznym zadaniem jest zapewnienie prawidłowego i ostrożnego zarządzania zakładem ubezpieczeń. Osoba nadzorująca funkcję compliance została zakwalifikowana jako pełniąca funkcję kluczową w zakładzie ubezpieczeń. Kwalifikacja ta determinuje obowiązek spełnienia przez tę osobę określonych wymagań, takich jak:

- posiadanie pełnej zdolności do czynności prawnych;

- posiadanie wyższego wykształcenia uzyskanego w Polsce lub wykształcenia uzyskanego w innym państwie, a będącego wykształceniem wyższym w rozumieniu właściwych przepisów tego państwa;

- brak skazania wyrokiem sądu za umyślne przestępstwo lub umyślne przestępstwo skarbowe prawomocnym;

- posiadanie doświadczenie zawodowego niezbędnego do wykonywania nadzorowanej kluczowej funkcji;

- dawanie rękojmi wykonywania zadań w sposób należyty.

Wśród wymienionych wymogów szczególne znaczenie KNF przywiązuje do posiadania przez osobę nadzorującą funkcję zgodności doświadczenia zawodowego niezbędnego do wykonywania tejże funkcji oraz dawania przez nią rękojmi wykonywania zadań w sposób należyty? Kryteria te, zdaniem nadzoru, należy oceniać w kontekście zasady proporcjonalności, odnosząc je do skali i złożoności działalności zakładu ubezpieczeń lub ryzyka, na jakie jest narażony, a także swego rodzaju prognozy pełnienia funkcji przez daną osobę w oparciu o jej dotychczasowe doświadczenie zawodowe. W szczególności zaś - do oceny dotychczasowego doświadczenia zawodowego danej osoby, w tym stwierdzonych nieprawidłowości w obszarze jej odpowiedzialności. Nadzorca stoi na stanowisku, że „działania ludzkie są powtarzalne i skoro raz dana osobą dopuściła się nieprawidłowości, to ryzyko ich dopuszczania przez daną osobę w przyszłości jest znacząco wyższe".

Ocena spełnienia wymogów przez kandydata na osobę nadzorującą funkcję zgodności spoczywa zarówno na organach statutowych zakładu ubezpieczeń, tj. zarządzie i radzie nadzorczej, jak i na komitecie audytu. Organy te, zdaniem nadzorcy, nie powinny ograniczać się jedynie do oceny

6. Ustawa z dnia 11 września 2015 r. o działalności ubezpieczeniowej i reasekuracyjnej (t. jedn. 2018, poz. 999 z późn. zm.J.

7. Komunikat z dnia 20 sierpnia 2018 r. w sprawie roli i znaczenia realizacji przez zakłady ubezpieczeń i zakłady reasekuracji funkcji zgodności z przepisami, www. knf.gov.pl [dostęp: 19.12.2018]. 
kwalifikacji merytorycznych kandydata, ale powinny również ustalać, czy dana osoba odznacza się zdolnościami do niezależnego pełnienia funkcji zgodności. Każdy z wymienionych wyżej organów zakładu ubezpieczeń winien wykazać się aktywnością w ocenie kandydata i nie ograniczać się do automatycznej akceptacji kandydata w oparciu o rekomendacje zarządu.

W tym miejscu należy wskazać, że rekomendacje KNF nie są przepisami prawa powszechnie obowiązującego, ale stanowią wyraz oczekiwań nadzorczych skierowanych do zakładów ubezpieczeń lub reasekuracji odnośnie do prowadzonej przez nich działalności. Oczekiwania nadzorcze wyrażane są także w formie stanowisk lub komunikatów do określonej grupy adresatów. Sama rekomendacja nadzorcza stanowi wskazanie, jaki sposób postępowania przez zakład ubezpieczeń lub reasekuracji jest przez nadzór aprobowany, a tym samym - jaki nie zostanie przez KNF zakwestionowany ${ }^{8}$. W konsekwencji - rekomendacje stanowia wyraz postrzegania przez KNF określonych obszarów działalności zakładu ubezpieczeń, a niezgodne z nimi postępowanie podmiotu nadzorowanego może w sytuacjach określonych w przepisach prawa spowodować wszczęcie działań nadzorczych ${ }^{9}$. Podkreślić należy jednak, że samo niestosowanie się przez zakład ubezpieczeń do rekomendacji nie może stanowić podstawy do nałożenia przez KNF sankcji nadzorczych. Okolicznością, która będzie stanowiła podstawę do zastosowania przez Komisję instrumentów nadzorczych, będzie naruszenie obowiązującego przepisu prawa. Nie można jednak wykluczyć sytuacji, w której określona rekomendacja będzie zawierała w sobie treść normy prawnej ${ }^{10}$.

Wśród przepisów prawa i oczekiwań nadzorczych wpływających na kształt funkcji compliance w zakładach ubezpieczeń należy wyróżnić:

- Rozporządzenie delegowane Komisji (UE) nr 2015/35 z dnia 10 października 2014 roku uzupełniające Dyrektywę Solvency II;

- Wytyczne Europejskiego Urzędu Nadzoru Ubezpieczeń i Pracowniczych Programów Emerytalnych (EIOPA) dotyczące zarządzania zakładem ubezpieczeń;

- Zasady Ładu Korporacyjnego dla instytucji nadzorowanych, wydane przez Komisję Nadzoru Finansowego;

- Międzynarodowe standardy dotyczące prowadzenia działalności ubezpieczeniowej i zasad nadzoru ubezpieczeniowego, wydane przez Międzynarodowe Stowarzyszenie Nadzorców Ubezpieczeniowych (IAIS);

- $\quad$ Normę ISO 19600:2014.

Szczegółowe zadania dla funkcji compliance w zakładzie ubezpieczeń oraz sposób ich realizacji został określony natomiast w art. 270 Rozporzadzenia delegowanego Komisji (UE) nr 2015/35. W świetle tego przepisu funkcja compliance w zakładzie ubezpieczeń:

- ustanawia zasady i plan zapewnienia zgodności z przepisami:

- w zasadach dotyczących zapewnienia zgodności z przepisami określa się zadania, kompetencje i obowiązki sprawozdawcze przypisane funkcji zgodności z przepisami;

- w planie zapewnienia zgodności z przepisami wymienia się planowane działania funkcji zgodności z przepisami, które uwzględniają wszystkie odpowiednie obszary działalności zakładów

8. B. Wojno, Komentarz do art. 365 ustawy o działalności ubezpieczeniowej i reasekuracyjnej, [w:] Ustawa o działalności ubezpieczeniowej i reasekuracyjnej. Komentarz, [red.] M. Szczepańska, P. Wajda, Wolters Kluwer, Warszawa 2017.

9. Ibidem.

10. Ibidem. 
Rola funkcji compliance w zarządzaniu ryzykiem braku zgodności w zakładzie ubezpieczeń

ubezpieczeń i zakładów reasekuracji oraz ich ekspozycję na ryzyko związane z przestrzeganiem przepisów;

- ocenia adekwatność środków przyjmowanych przez zakład ubezpieczeń lub zakład reasekuracji w celu zapobiegania niezgodności z przepisami.

Wśród regulacji wpływających na kształt funkcji zgodności w zakładzie ubezpieczeń warto również wskazać na międzynarodowe standardy dotyczące prowadzenia działalności ubezpieczeniowej i zasad nadzoru ubezpieczeniowego wydane przez Międzynarodowe Stowarzyszenie Nadzorców Ubezpieczeniowych (IAIS). W wytycznej nr 8.4 IAIS rekomenduje zakładom ubezpieczeń posiadanie efektywnego systemu zgodności, który powinien wspierać ubezpieczyciela w spełnianiu prawnych i regulacyjnych zobowiązań oraz promować kulturę zgodności. W celu realizacji ww. zadania, zarząd powinien przyjać kodeks dobrych praktyk. Będzie on punktem odniesienia dla prowadzonej przez zakład ubezpieczeń działalności, która powinna być zgodna z przepisami prawa powszechnie obowiązującymi oraz przyjętymi standardami etycznymi. Wytyczne odnoszą się również do organizacji funkcji compliance w strukturach zakładu ubezpieczeń oraz osoby do kierującej ta jednostką (Chief Compliance Officer). Osoba powołana do nadzorowania funkcji zgodności powinna mieć zapewniony bezpośredni dostęp do zarządu w celu informowania o:

- najważniejszych ryzykach compliance, z jakimi łączy się działalność ubezpieczyciela, oraz o działaniach podjętych w celu ich zwalczania;

- ocenie, w jaki sposób poszczególne działy i komórki realizuja standardy i cele compliance; problemach personalnych i konfliktach interesów;

- grzywnach i innych sankcjach dyscyplinarnych nałożonych przez odpowiednie organy na ubezpieczyciela lub jego pracowników ${ }^{11}$.

Norma ISO 19600:2014 jest z pewnością punktem odniesienia dla przedsiębiorców, którzy planują wdrożyć funkcję compliance, w tym dla zakładów ubezpieczeń. Norma ta określa generalne standardy związane z ukształtowaniem compliance. Treść normy ISO jest międzynarodowym standardem i w tym znaczeniu nie powinna być utożsamiana z wymogiem, który powinni spełnić przedsiębiorcy. Swoim zakresem obejmuje rekomendacje związane z wdrożeniem, realizowaniem oraz rozwijaniem funkcji compliance. Opiera się na zasadach dobrego rządzenia, proporcjonalności, transparentności i trwałości. Zgodnie z treścią normy efektem posiadania skutecznej funkcji compliance jest osiaganie przez organizację zakładanych celów biznesowych poprzez przestrzeganie prawa oraz przyjętych standardów postępowania, a także norm etycznych. Podstawowym zadaniem organizacji podejmowanym w celu zapewnienia skutecznej funkcji zgodności jest zidentyfikowanie wszelkich wymogów związanych z prowadzoną działalnością. W tym kontekście organizacja powinna dokonać samooceny prowadzonej działalności (charakter prowadzonej działalności, świadczonych usług lub produktów).

\section{Organizacja funkcji compliance w zakładach ubezpieczeń}

Przepisy prawa nie ingeruja szczegółowo w sposób ukształtowania i funkcjonowania funkcji compliance w strukturze organizacyjnej zakładu ubezpieczeń. Obowiązujące wymogi prawne dotyczące funkcji zgodności z przepisami w zakładach ubezpieczeń koncentrują się na podstawowych aspektach

11. B. Mrozowska-Bartkiewicz, A. Wnęk, op. cit., s. 73. 
związanych wykonywaniem tej funkcji, takich jak: obowiązek ustanowienia compliance, opis roli tej funkcji oraz kryteriów, jakie musi spełnić osoba zamierzająca nadzorować jej wykonywanie. W tym miejscu należy wskazać, że brak ustanowienia przez zakład ubezpieczeń funkcji zgodności może być sankcjonowany przez Komisję Nadzoru Finansowego w drodze środków nadzorczych określonych w u.dz.u.r. Sama struktura compliance w zakładzie ubezpieczeń powinna opierać się na właściwym i jasnym podziale zadań, który zapewni skuteczny proces decyzyjny, zapobiegnie konfliktom interesów oraz zapewni skuteczny system przekazywania informacji12 ${ }^{12}$ Jednocześnie, zgodnie z zasada proporcjonalności, system zgodności z przepisami powinien być adekwatny do charakteru, skali i złożoności działalności danego zakładu ubezpieczeń. Proporcjonalny system compliance powinien zapewnić jego efektywną realizację ${ }^{13}$.

Kształtując funkcję compliance w zakładzie ubezpieczeń warto również wziąć pod uwagę stanowisko KNF dnia 20 sierpnia 2018 roku w sprawie roli i znaczenia realizacji przez zakłady ubezpieczeń i zakłady reasekuracji funkcji zgodności z przepisami ${ }^{14}$. W przedstawionej wizji funkcji zgodności z przepisami, KNF zwraca uwagę, że jej rdzeniem jest zapewnienie zgodności z szeroko rozumianymi przepisami prawa, włącznie z regulacjami dotyczącymi zapobiegania tzw. praniu brudnych pieniędzy, ochrony danych osobowych, jak również zapewnieniu zgodności z rekomendacjami nadzorczymi. Realizacja ustawowego zadania funkcji compliance, jakim jest zapewnienie zgodności z przepisami prawa, nie powinna kolidować z ewentualnymi dodatkowymi zadaniami wykonywanymi przez tę funkcję, chociażby związanymi implementacją i stosowaniem regulacji wewnętrznych obowiązujących w grupie kapitałowej, do której należy dany zakład ubezpieczeń. Niedopuszczalne, zdaniem nadzorcy, jest takie kształtowanie jednostki compliance, w ramach którego prymat przypisuje się zadaniom innymi niż zapewnienie zgodności z przepisami prawa. Takie kształtowanie hierarchii zadań przez akcjonariusza może być ocenione jako nieuprawnione wywieranie wpływu na autonomię funkcji compliance.

W świetle stanowiska KNF nieprawidłowości w działaniu funkcji zgodności z przepisami skutkują odpowiedzialnością zarówno po stronie osób nadzorujących wypełnianie funkcji kluczowej, jak i po stronie prezesa zarządu i pozostałych członków zarządu. Źródłami nieprawidłowości w działaniu funkcji compliance mogạ być nieodpowiednia struktura organizacyjna, nieodpowiednio zorganizowany system zarządzania, błędna kultura organizacyjna i kultura zarządzania ryzykiem, nieodpowiednie postawy osób wchodzacych w skład kadry kierowniczej zakładu ubezpieczeń czy wreszcie - niezapewniene niezależności i obiektywizmu w działaniu funkcji zgodności.

Nie powinno ulegać wątpliwości, że odpowiedzialność osoby nadzorującej funkcję compliance oraz członków zarządu zakładu ubezpieczeń za nieprawidłowości w działaniu tejże funkcji ma charakter odpowiedzialności administracyjnoprawnej, której podstawą może być naruszenie określonych przepisów ustawy u.dz.u.r. Samo naruszenie przepisów prawa jest jedną z przesłanek możliwości zastosowania przez KNF środków nadzorczych, o których mowa w art. 362 ust. 1 u.dz.u.r. w zw. z art. 362 ust. 2 pkt 1 tej ustawy. W świetle tych przepisów jednym z przysługujących KNF środków nadzorczych jest możliwość nałożenia kary pieniężnej na członka zarządu, w przypadku gdy zakład ubezpieczeń prowadzi działalność z naruszeniem prawa.

12. D. Leśniak, Komentarz do art. 45 ustawy o działalności ubezpieczeniowej i reasekuracyjnej, [w:] Ustawa o działalności ubezpieczeniowej i reasekuracyjnej...

13. P. Wajda, Ibidem.

14. Komunikat KNF z dnia 20 sierpnia 2018 r. w sprawie... 
Pojęcie funkcji zgodności z przepisami na gruncie Dyrektywy Solvency /l powinno być rozumiane jako możliwość podjęcia praktycznych zadań ${ }^{15}$. W świetle powyższego nadrzędną rola jednostki ds. compliance jest koordynowanie procesu zarządzania ryzykiem braku zgodności w ten sposób, aby poziom tego ryzyka był akceptowalny z perspektywy bezpieczeństwa zakładu ubezpieczeń. W ramach kształtowania systemu zgodności w zakładzie ubezpieczeń rozważyć należy również jego model, tj. ustalić, czy compliance powinno stanowić element systemu kontroli wewnętrznej, tak jak zostało to określone w art. 64 ust. 1 u.dz.u.r., czy powinno być pojmowane szerzej, jako element systemu zarządzania ryzykiem. Polski ustawodawca w przyjałł w u.dz.u.r. relację rozłączności funkcji zgodności z przepisami od funkcji zarządzania ryzykiem. Inaczej jednak funkcję compliance kwalifikuje Komisja Nadzoru Finansowego, która w wydanych zasadach ładu korporacyjnego dla instytucji nadzorowanych nie przesądza, czy funkcja ta jest jedynie elementem systemu kontroli wewnętrznej, czy obejmuje również system zarządzania ryzykiem ${ }^{16}$. Tym samym wydaje się, że w ten sposób pozostawia pewną swobodę instytucjom finansowym, w tym zakładom ubezpieczeń, w organizacji funkcji compliance w ich wewnętrznych strukturach. Wskazana powyżej koncepcja rozumienia systemu zgodności przez nadzór finansowy została również wyrażona w uchwale nr 258/2011 KNF kierowanej do sektora bankowego ${ }^{17}$.

Odnosząc się do samego usytuowania jednostki ds. compliance w strukturze organizacyjnej zakładu ubezpieczeń, należy wskazać na pewne oczekiwania nadzorcze wyrażone zarówno w ramach Zasad Ładu Korporacyjnego dla instytucji nadzorowanych, jak i w ramach stanowisk KNF z dnia 16 lutego 2016 roku w sprawie wymagań w zakresie systemu zarządzania funkcjonującego w zakładzie ubezpieczeń / reasekuracji oraz z dnia 2 sierpnia 2018 roku w sprawie roli i znaczenia realizacji przez zakłady ubezpieczeń i zakłady reasekuracji funkcji zgodności z przepisami ${ }^{18}$.

Zgodnie z par. 47 Zasad ładu korporacyjnego, „1. Instytucja nadzorowana powinna opracować i wdrożyć efektywną, skuteczną i niezależną funkcję zapewniania zgodności działania instytucji nadzorowanej z przepisami prawa i regulacjami wewnętrznymi oraz z uwzględnieniem rekomendacji nadzorczych. 2. Sposób organizacji funkcji zapewnienia zgodności powinien gwarantować niezależność wykonywania zadań w tym zakresie". W świetle powyższego, Komisja Nadzoru Finansowego oczekuje, że instytucje finansowe, w tym zakłady ubezpieczeń, tak ukształtują funkcję compliance w swoich strukturach, by zapewnić jej niezależność i efektywność.

Warto również zwrócić uwagę, że zgodnie z Zasadami Ładu Korporacyjnego status osoby kierującej jednostką ds. zgodności jest zrównany ze statusem osoby kierującej jednostką ds. audytu wewnętrznego. Jednocześnie, wskazane powyżej osoby powinny mieć zapewnioną możliwość bezpośredniego komunikowania się z zarządem oraz radą nadzorczą, a także komitetem audytu.

15. D. Leśniak, op. cit.

16. Ł. Cichy, op. cit., s. ?-8.

17. Uchwała Komisji Nadzoru Finansowego nr 258/2011 z dnia 4 października 2011 r. w sprawie szczegółowych zasad funkcjonowania systemu zarządzania ryzykiem i systemu kontroli wewnętrznej oraz szczegółowych warunków szacowania przez banki kapitału wewnętrznego i dokonywania przeglądów procesu szacowania i utrzymywania kapitału wewnętrznego oraz zasad ustalania polityki zmiennych składników wynagrodzeń osób zajmujących stanowiska kierownicze w banku.

18. Stanowiska Komisji Nadzoru Finansowego z dnia 16 lutego 2016 r. w sprawie wymagań w zakresie systemu zarządzania funkcjonującego w zakładzie ubezpieczeń / reasekuracji oraz z dnia 2 sierpnia 2018 r. sprawie roli i znaczenia realizacji przez zakłady ubezpieczeń i zakłady reasekuracji funkcji zgodności z przepisami, www.knf.gov.pl [dostęp: 19.12.2018]. 
W ramach tych uprawnień osoby te powinny mieć możliwość bezpośredniego raportowania do wymienionych organów. KNF oczekuje, że zarówno osoba kierująca jednostką ds. zgodności, jak i osoba kierująca jednostką ds. audytu wewnętrznego będą uczestniczyły w posiedzeniach zarządu i rady nadzorczej lub komitetu audytu, jeżeli przedmiotem posiedzenia są zagadnienia związane z systemem kontroli wewnętrznej, funkcją audytu wewnętrznego lub funkcją zapewnienia zgodności. Podkreślenia wymaga również, że zgodnie z Zasadami Ładu Korporacyjnego powołanie lub odwołanie osoby kierującej jednostką compliance odbywa się za zgodą rady nadzorczej lub komitetu audytu. W uzupełnieniu warto zwrócić uwagę, że zakład ubezpieczeń jest zobowiązany do informowania organu nadzoru o zmianach na stanowisku osoby nadzorującej funkcję compliance w terminie $?$ dni od dnia dokonania takiej zmiany. KNF może również w drodze decyzji zakazać danej osobie nadzorowania funkcji zgodności w sytuacji stwierdzenia, że nie spełnia ona wymogów określonych w u.dz.u.r.

KNF oczekuje również, że członkowie zarządu nie będą łączyć stanowisk nadzorujących inne kluczowe funkcje, tj. funkcję zgodności, funkcję zarządzania ryzykiem, funkcję audytu wewnętrznego oraz funkcję aktuarialną ${ }^{19}$. Powyższe Komisja wywodzi z odmiennego charakteru obowiązków spoczywających na zarządzie i obowiązków przypisanych nadzorującym inne kluczowe funkcje w zakładzie ubezpieczeń. Zdaniem organu nadzoru rolą osób nadzorujących inne kluczowe funkcje, w tym funkcję zgodności z przepisami, jest służenie członkom zarządu radą i wiedzą ekspercką.

\section{Funkcjonowanie jednostki compliance w zakładach ubezpieczeń}

Tworząc jednostkę ds. compliance w zakładzie ubezpieczeń, można jako punkt odniesienia przyją́ następujące modele (analogicznie do modeli występujących w bankach ${ }^{20}$ ):

Model centralny, w którym za cały proces zarządzania ryzykiem braku zgodności odpowiada jednostka ds. zgodności, współpracująca z innymi jednostkami zakładu ubezpieczeń, w tym w szczególności z jednostkami biznesowymi oraz operacyjnymi. W tym modelu podlega ona bezpośrednio pod zarząd zakładu ubezpieczeń.

Model hybrydowy, w którym w proces zarządzania ryzykiem braku zgodności zaangażowane są wszystkie jednostki zakładu ubezpieczeń. Jednostka compliance jest w tym przypadku odpowiedzialna za całościowe zapewnianie zgodności oraz całościowy proces zarządzania ryzkiem braku zgodności. Przejawia się to w szczególności w monitorowaniu oraz weryfikacji jednostek biznesowych w zakresie prowadzonej przez nich działalności oraz w raportowaniu do zarzadu i rady nadzorczej.

Model rozproszony, w którym funkcja compliance jest realizowana przez wszystkie jednostki zakładu ubezpieczeń. W tym modelu jednostka ds. zgodności jest jedynie pośrednikiem w przekazywaniu informacji do zarządu lub staje się wręcz zbędna.

Wybór modelu funkcji compliance zależy od decyzji zakładu ubezpieczeń. Aktualnie nie ma bowiem w przepisach prawa wymogu przyjęcia określonego wzorca funkcji compliance przez zakład ubezpieczeń. Z pewnościa jednak przy wyborze modelu funkcji zgodności zakład ubezpieczeń

19. Ibidem.

20. Ł. Cichy, op. cit., s. 10. 
powinien kierować się zasadą proporcjonalności. Zgodnie z tą zasadą, wybór modelu powinien być adekwatny do charakteru, skali i złożoności działalności danego zakładu ubezpieczeń.

Pewne wskazówki co do modelu funkcji zgodności, jaki powinien funkcjonować w zakładzie ubezpieczeń, zostały wskazane przez KNF w Zasadach Ładu Korporacyjnego. W świetle par. 47 ust. 2 oraz par. 49 tychże zasad jednostka compliance powinna uczestniczyć w procesie zarządzania ryzykiem braku zgodności. Rola ta powinna skupiać się bardziej na koordynacji samego procesu, raportowaniu do rady nadzorczej i zarządu oraz służeniu wiedzą ekspercką tymże organom $^{21}$. W kontekście powyższego wydaje się, że preferowanym przez organ nadzoru modelem funkcji compliance jest model hybrydowy. Wskazane powyżej stanowisko jest zgodne z tzw. modelem trzech linii obrony przyjętym w Dyrektywie Solvency II, w świetle którego compliance jest właścicielem procesu zarządzania ryzykiem braku zgodności, a właścicielem samego ryzyka sa jednostki biznesowe oraz operacyjne.

W świetle modelu trzech linii obrony funkcja zgodności odgrywa rolę doradczą oraz koordynująca proces zarządzania ryzykiem braku zgodności poprzez jego monitorowanie i zarządzanie nim. Sama rola funkcji compliance nie może polegać na akceptowaniu zidentyfikowanego ryzyka braku zgodności na potrzeby procesów decyzyjnych po stronie jednostek biznesowych lub zarządu ${ }^{22}$. W tym kontekście szczególnie krytycznie należy ocenić wywieranie presji na funkcję zgodności przez jednostki biznesowe lub kadrę kierowniczą zakładu ubezpieczeń w celu akceptacji przez funkcję compliance zidentyfikowanego ryzyka braku zgodności bądź też takie wywieranie presji aby tego ryzyka funkcja compliance nie sygnalizowała ${ }^{23}$. Kluczowym elementem gwarantującym niezależność funkcji zgodności z przepisami jest taki kształt organizacyjny tej funkcji, który uniemożliwi wywieranie wpływu na jej pracowników poprzez możliwość pogorszenia ich sytuacji pracowniczej ${ }^{24}$.

W literaturze przedmiotu podkreśla się, że funkcja zgodności z przepisami powinna jasno wskazywać warunki graniczne, poza które jednostki biznesowe i operacyjne nie powinny wykraczać25. Jednocześnie trzeba zastrzec, że przy tworzeniu funkcji compliance przez zakład ubezpieczeń należy uwzględniać właściwe wymogi prawne oraz oczekiwania nadzorcze odnoszące się do tej funkcji. W tym miejscu konieczne jest wskazanie, że o ile w przypadku przepisów prawnych zakład ubezpieczeń jest zobowiązany spełnić wymogi pod groźbą potencjalnych sankcji, to w sytuacji oczekiwań nadzorczych wyrażonych w formie stanowisk lub rekomendacji zakład ma pewna swobodę w ich realizacji i może kierować się zasada „zastosuj lub wyjaśnij” (comply or explain). W efekcie przy tworzeniu funkcji zgodności zakład ubezpieczeń może - powołując się na zasadę proporcjonalności - zdecydować o innym zorganizowaniu tej funkcji niż rekomendowana przez organ nadzoru, o ile znajduje to uzasadnienie w charakterze, skali i działalności zakładu.

Odnosząc się do właściwości compliance, należy stwierdzić, że w świetle art.64 ust. 2 u.dz.u.r. przedmiotem zainteresowania tej jednostki powinny być wszystkie regulacje prawne, w tym wewnętrzne, które oddziałują lub mogą oddziaływać na działalność zakładu ubezpieczeń. W kontekście

21. Ibidem, s. 12.

22. Komunikat KNF z dnia 20 sierpnia 2018 r. w sprawie...

23. Ibidem.

24. Ibidem.

25. K. Rajewski, Funkcja compliance w strukturze organizacyjnej zakładu ubezpieczeń - wyzwania i aspekty praktyczne, „Prawo Asekuracyjne” 2018, nr 3, s. 39. 
zakresu regulacji, które mają zastosowanie do działalności zakładu ubezpieczeń, należy stwierdzić, że najbardziej optymalnym modelem realizacji funkcji compliance będzie tzw. model hybrydowy ${ }^{26}$. Tak jak wskazałem powyżej, w tym modelu funkcja compliance jest realizowana przez wszystkie jednostki zakładu ubezpieczeń, a komórka ds. zgodności koordynuje systemowo proces zapewniania zgodności oraz zarządzania ryzykiem braku zgodności w ramach całego zakładu ubezpieczeń. Nie ulega wattpliwości, że szczególnym przedmiotem zainteresowania jednostki compliance powinny być przede wszystkim przepisy prawa regulujące stricte działalność ubezpieczeniowa oraz regulacje, których nieprzestrzeganie generuje największe ryzyko. W ramach działalności zakładów ubezpieczeń będą to z pewnością takie sfery, jak ${ }^{27}$ :

- zgodność działalności przedsiębiorstwa z przepisami prawa polskiego i unijnego oraz zaleceniami instytucji nadzorczych i innych podmiotów mających wpływ na praktyki obowiązujące na rynkach finansowych;

- $\quad$ przeciwdziałanie praniu brudnych pieniędzy, finansowaniu terroryzmu, korupcji i innym nadużyciom wśród klientów, pracowników i kontrahentów oraz ochrona tajemnic prawnie chronionych;

- ochrona informacji poufnych oraz danych osobowych, nadzór nad przepływem informacji poufnych;

- zarządzanie konfliktami interesów;

- zapewnienie, że pracownicy przedsiębiorstwa będa przestrzegać zasad etyki i odpowiednich praktyk rynkowych;

- ustalanie zasad etycznego postępowania w prowadzeniu działalności ubezpieczeniowej;

- reklama produktów ubezpieczeniowych;

- przyjmowanie zgłoszeń, postępowanie wyjaśniające, wypracowanie standardów chroniących pracowników zgłaszających nieprawidłowości (w tym whistleblowing);

- zarządzanie ryzykiem operacyjnym w obszarze compliance;

- $\quad$ kontakty z instytucjami nadzorczymi, w tym dystrybucja korespondencji przesyłanej przez te instytucje i odpowiedzi na ich zapytania;

- zagadnienia związane z outsourcingiem ubezpieczeniowym;

- uczestniczenie w rozwijaniu nowych modeli biznesowych lub tworzeniu nowych produktów, z uwzględnieniem regulacji obowiązujących w tym zakresie oraz właściwej komunikacji;

- nadzór nad polityką związaną z otrzymywaniem i wręczaniem przez pracowników prezentów oraz organizacją imprez z udziałem klientów;

- przeprowadzanie szkoleń i akcji informacyjnych dla pracowników w zakresie kultury compliance.

\section{Proces zarządzania ryzykiem braku zgodności w zakładzie ubezpieczeń na przykładzie unormowań obowiązujących w bankach}

W świetle par. 50 ust. 2 Zasad Ładu Korporacyjnego proces zarządzania ryzykiem w instytucjach finansowych składa się poszczególnych czynności, które są ze sobą związane. Proces ten został uregulowany w rozporządzeniu Ministra Rozwoju i Finansów z dnia 6 marca 2017 roku w sprawie systemu zarządzania ryzykiem i systemu kontroli wewnętrznej, polityki wynagrodzeń oraz

26. Ibidem, s. 19-20.

27. B. Mrozowska-Bartkiewicz, A. Wnęk, op. cit., s. 7 ?. 
szczegółowego szacowania kapitału wewnętrznego w bankach (Dz. U. 2017.637). Jednocześnie należy zwrócić uwagę na oczekiwania nadzorcze co do procesu zarządzania ryzykiem braku zgodności w bankach wyrażone w rekomendacji $\mathrm{H}$, dotyczącej systemu kontroli wewnętrznej w bankach. Jakkolwiek regulacje te i oczekiwania nadzorcze kierowane są do banków, to moga one stanowić punkt odniesienia do zobrazowania modelu procesu zarządzania ryzykiem braku zgodności, który może występować w zakładach ubezpieczeń.

W świetle par. 37 pkt. 4-8 ww. rozporządzenia, do obowiązków komórki do spraw zgodności należy:

- identyfikowanie ryzyka braku zgodności, w szczególności przez analizę przepisów prawa, regulacji wewnętrznych banku, standardów rynkowych oraz wyników wewnętrznych postępowań wyjaśniających przeprowadzanych przez komórkę do spraw zgodności;

- ocena ryzyka braku zgodności przez pomiar lub szacowanie tego ryzyka;

- projektowanie i wprowadzanie mechanizmów kontroli ryzyka braku zgodności, bazujacych na ocenie ryzyka braku zgodności;

- monitorowanie wielkości i profilu ryzyka braku zgodności po zastosowaniu mechanizmów kontroli ryzyka braku zgodności;

- okresowe przekazywanie raportów w zakresie ryzyka braku zgodności do zarządu i rady nadzorczej lub komitetu audytu, jeżeli został powołany.

\subsection{Identyfikacja ryzyka braku zgodności}

Pierwszą składową procesu zarządzania ryzykiem braku zgodności jest jego identyfikacja. Czynność ta ma na celu zlokalizowanie obszarów, w których może występować ryzyko braku zgodności. W tym celu jednostka ds. compliance powinna mieć zagwarantowany dostęp do istotnych źródeł informacji o działalności biznesowej i operacyjnej zakładu ubezpieczeń. Tylko w ten sposób funkcja zgodności z przepisami będzie mogła w sposób niezależny i obiektywny realizować swoje zada$n^{2}{ }^{28}$. Powyższe może realizować się chociażby poprzez uczestnictwo jednostki ds. compliance w pracach nad wdrożeniem lub zmianą produktów oferowanych przez zakład ubezpieczeń. Udział komórki ds. zgodności w tym procesie wymagany jest zreszta przez Komisję Nadzoru Finansowego w świetle rekomendacji dotyczących systemu zarządzania produktem. Zgodnie bowiem z rekomendacją nr 11: „Zakład powinien przeprowadzić szczegółowe analizy produktów przed ich wprowadzeniem do obrotu oraz każdorazowo w przypadku zmiany docelowej grupy klientów lub istotnych zmian w produktach". W ramach analiz produktów zakład ubezpieczeń powinien przeprowadzać:

- analizę jakościowa polegającą na ocenie zgodności z obowiązującymi przepisami prawa, wytycznymi i rekomendacjami organu nadzoru oraz przyjętymi przez sam zakład regulacjami wewnętrznymi;

- $\quad$ analizę w zakresie występowania w produktach postanowień, które zostały uznane za niedozwolone postanowienia umowne lub postanowienia o treści analogicznej;

- analizę potencjalnych ryzyk związanych z produktem, w tym dotyczących nieadekwatności składki oferowanej przez zakład.

Jakkolwiek proces związany ze zmianą lub wdrożeniem produktów oferowanych przez zakład nie powinien być jedynym źródłem informacji o potencjalnych ryzykach braku zgodności,

28. Komunikat KNF z dnia 20 sierpnia 2018 r. w sprawie... 
to Komisja Nadzoru Finansowego w Rekomendacji H dotyczącej systemu kontroli wewnętrznej w bankach wyróżnia również następujące podstawowe źródła informacji, które powinny być wykorzystywane w ramach identyfikacji ryzyka braku zgodności (zgodnie z rekomendacją nr 15.2):

- zmiany przepisów prawa, regulacji wewnętrznych i standardów rynkowych;

- prowadzone w banku rejestry i dokumentacje (np. rejestr strat ryzyka operacyjnego);

- informacje uzyskiwane od innych komórek organizacyjnych w ramach wykonywania przypisanych im obowiązków, w tym zwłaszcza w ramach realizowanego przez te komórki procesu niezależnego monitorowania;

- ustalenia dokonane przez komórkę do spraw zgodności w związku z bieżącą weryfikacją oraz testowaniem, wykonywanymi przez tę komórkę;

- wyniki wewnętrznych postępowań wyjaśniających przeprowadzanych przez komórkę do spraw zgodności lub inne komórki organizacyjne banku;

- nieprawidłowości zidentyfikowane przez bank w ramach wszystkich trzech linii obrony;

- informacje pochodzace z anonimowego kanału powiadamiania o naruszeniach;

- ustalenia wynikające z czynności nadzorczych wykonywanych przez uprawnione instytucje (np. KNF) oraz czynności realizowanych przez inne upoważnione instytucje (np. UOKIK, Rzecznik Finansowy).

\subsection{Ocena ryzyka braku zgodności}

Drugą składową procesu zarządzania ryzykiem braku zgodności jest ocena ryzyka, zwana również analiza, pomiarem albo szacowaniem ryzyka. Ocena ryzyka następuje po jego zidentyfikowaniu i polega na jego oszacowaniu ${ }^{29}$. Niemniej jednak, ryzyko braku zgodności jest ryzykiem trudno mierzalnym. W jego ocenie kluczowe znaczenia mają metody jakościowe, polegające na eksperckim pomiarze ryzyka wykonywanym przez oficerów zgodności (compliance officer). Efektem tej oceny jest określenie poziomu zidentyfikowanego ryzyka (np. poziom wysoki, średni bądź niski) na podstawie przyjętej procedury lub metodyki. W tym znaczeniu ocena ryzyka braku zgodności może polegać na szacowaniu wysokości strat finansowych i niefinansowych, jakie może ponieść zakład ubezpieczeń w wyniku ziszczenia się tego ryzyka. Straty te moga wynikać z kar pieniężnych nałożonych przez regulatorów takich jak Urząd Ochrony Konkurencji i Konsumentów czy Komisja Nadzoru Finansowego. Przykładowo: w przypadku zidentyfikowania ryzyka braku zgodności polegającego na potencjalnym naruszeniu zbiorowych interesów konsumentów, wysokość kary, jaką może nałożyć Prezes Urzędu Ochrony Konkurencji i Konsumentów w przypadku ziszczenia się tego ryzyka, wynosi $10 \%$ obrotu osiagnniętego w roku obrotowym poprzedzajacym rok nałożenia kary. Powyższe nie uwzględnia strat, jakie mogą wyniknąć ze sporów procesowych z poszczególnymi klientami, a także strat wynikających z utraty wiarygodności wśród klientów. W ramach oceny ryzyka braku zgodności należy wyróżnić następujące metody (zgodnie z rekomendacją KNF nr 16.2 dotyczącą systemu kontroli wewnętrznej w bankach):

- samoocena ryzyka,

- analizy scenariuszowe,

- analizy luk regulacyjnych,

- wskaźniki ryzyka braku zgodności.

29. Ł. Cichy, op. cit., s. 21. 


\subsection{Kontrola ryzyka braku zgodności}

Stosowanie mechanizmów ograniczających ryzyko to kolejny etap w procesie zarządzania ryzykiem braku zgodności. Mechanizmy te pełnią funkcję prewencyjną, a ich celem jest zminimalizowanie ryzyka braku zgodności ${ }^{30}$. W świetle par. 36 ust. 1 rozporządzeniu Ministra Rozwoju i Finansów z dnia 6 marca 2017 roku w sprawie systemu zarządzania ryzykiem i systemu kontroli wewnętrznej, polityki wynagrodzeń oraz szczegółowego szacowania kapitału wewnętrznego w bankach, należy wyróżnić następujące rodzaje mechanizmów kontrolnych:

- procedury,

- podział obowiązków,

- autoryzacja, w szczególności autoryzacja operacji finansowych i gospodarczych,

- kontrola dostępu,

- kontrola fizyczna,

- proces ewidencji operacji finansowych i gospodarczych w systemach: księgowym, sprawozdawczym i operacyjnym,

- inwentaryzacja,

- dokumentowanie odstępstw,

- wskaźniki wydajności,

- szkolenia.

Na uwagę zasługują również mechanizmy kontroli ryzyka określone przez KNF w Rekomendacji $\mathrm{H}$ dotyczącej systemu kontroli wewnętrznej (rekomendacja nr 17.2.):

- analiza nowych produktów i usług wprowadzanych do oferty banku;

- analiza modyfikacji tych produktów i usług oraz analiza procesów sprzedażowych tych produktów i usług pod kątem zgodności z przepisami prawa, regulacjami wewnętrznymi i standardami rynkowymi;

- wydawanie szczegółowych wytycznych przez komórkę do spraw zgodności;

- koordynowanie procesu informowania o zmianach w przepisach prawa, regulacjach wewnętrznych i standardach rynkowych;

- uczestnictwo w kluczowych projektach wdrożeniowych, w kontekście zapewniania zgodności z przepisami prawa, regulacjami wewnętrznymi i standardami rynkowymi ( o ile nie narusza to niezależności komórki do spraw zgodności w procesie testowania);

- przeprowadzanie lub zlecanie szkoleń w zakresie wskazanym przez komórkę do spraw zgodności;

- określenie wskaźników ryzyka braku zgodności.

\subsection{Monitorowanie ryzyka}

Monitorowanie zidentyfikowanego i ocenionego ryzyka braku zgodności ma na celu ustalenie, czy zastosowane mechanizmy ograniczające ryzyko zminimalizowały możliwość jego wystapienia, oraz ustalenie, czy poziom tego ryzyka jest akceptowalny z perspektywy przyjętej strategii zarządzania ryzkiem w zakładzie ubezpieczeń. Monitorowanie ryzyka należy postrzegać również jako

30. Ibidem, s. 20. 
kontrolę wcześniejszych etapów procesu zarządzania ryzykiem braku zgodności. Czynność ta ma na celu również wskazanie zarządowi oraz radzie nadzorczej, czy poziom ryzyka braku zgodności jest akceptowalny. Wśród narzędzi służących monitorowaniu ryzyka wyróżnia się ${ }^{31}$ :

- testy zgodności,

- ankiety, w tym ankiety samooceny,

- oceny dojrzałości modelu compliance,

- wskaźniki wykonania (np. odsetek przeszkolonych pracowników, rozpatrywanych skarg i wniosków klienta, tempo wdrażania i realizacji rekomendacji wewnętrznych oraz zaleceń pokontrolnych nadzorcy).

\subsection{Raportowanie do zarządu i rady nadzorczej}

Raportowanie stanowi ostatni element procesu zarządzania ryzykiem braku zgodności. W ramach tej czynności komórka ds. zgodności powinna informować cyklicznie (miesięcznie, kwartalnie i rocznie) oraz ad hoc (np. wewnętrzne postępowania wyjaśniające) zarząd i radę nadzorczą o poziomie i profilu ryzyka braku zgodności w zakładzie ubezpieczeń. Jednocześnie raporty powinny zawierać informacje o poszczególnych składowych procesu zarządzania ryzkiem braku zgodności, w tym o zidentyfikowanych ryzykach braku zgodności, ich ocenie, zastosowanych mechanizmach kontrolnych oraz wynikach z monitoringu tego ryzyka. Wydaje się, iż w celu zapewnienia przejrzystości raporty cykliczne powinny być kierowane zarówno do zarządu, jak i do rady nadzorczej.

\section{Podsumowanie}

Zasadniczym założeniem pracy była próba określenia znaczenia funkcji compliance w procesie zarządzania ryzykiem braku zgodności poprzez pryzmat funkcjonowania i organizacji tej jednostki w strukturach zakładu ubezpieczeń. Celem jednostki ds. zgodności z przepisami - jak i samego procesu zarządzania ryzykiem braku zgodności - powinno być ograniczanie ryzyka poprzez zapewnienie adekwatnych działań mitygujących. W tym kontekście rola compliance winna być postrzegana nie jako ograniczanie rozwoju biznesu, lecz jako szansa na zapobiegnięcie znacznym stratom finansowym wynikającym z materializacji ryzyka braku zgodności. Efektywna realizacja funkcji compliance pozwala bowiem jednostkom operacyjnym i biznesowym na podejmowanie świadomych decyzji co do akceptacji ryzyka. Powyższe ma szczególne znaczenie w dobie systematycznego wzrostu wymogów prawnych oraz nadzorczych dla instytucji finansowych, w tym związanego z tym ryzyka prowadzenia działalności oraz relacji z klientami (conduct risk). Efektem tej tendencji jest proporcjonalny wzrost ekspozycji zakładów ubezpieczeń na ryzyko poniesienia istotnych strat finansowych i niefinansowych związanych z naruszeniem określonych obowiązków.

Mając na uwadze powyższe, należy stwierdzić, że zapewnienie zgodności działalności zakładu ubezpieczeń z obowiązującym prawem, regulacjami wewnętrznymi oraz oczekiwaniami nadzorczymi niewatpliwie stanowi element bezpiecznego, stabilnego oraz ostrożnego zarzadzania. Świadome zarządzanie ryzykiem braku zgodności pozwala również ograniczyć ryzyko utraty reputacji, która ma kluczowe znaczenie dla instytucji finansowych jako instytucji zaufania publicznego.

31. Ibidem, s. 22. 
Organizacja jednostki ds. zgodności z przepisami leży w kręgu zainteresowania Komisji Nadzoru Finansowego, która zwraca uwagę, że nieprawidłowe działalnie tejże funkcji rodzi odpowiedzialność po stronie osoby ją nadzorującej, jak również po stronie członków zarządu zakładu ubezpieczeń. Nie ulega watpliwości, że wraz ze wzrostem regulacji rola i znaczenie funkcji zgodności na rynku ubezpieczeniowym będzie systematycznie wzrastać, tak jak ma to miejsce w bardziej rozwiniętych sferach rynku finansowego.

\section{Wykaz źródeł}

\section{Literatura:}

Cichy Ł., Funkcja compliance w bankach, CEDUR, Komisja Nadzoru Finansowego, Warszawa 2015. Hull J.C., Zarzqdzanie ryzykiem instytucji finansowych, PWN, Warszawa 2011.

Mrozowska-Bartkiewicz B., Wnęk A., Funkcja compliance w zakładzie ubezpieczeń, „Prawo Asekuracyjne" 2016, nr 1.

Rajewski K., Funkcja compliance w strukturze organizacyjnej zakładu ubezpieczeń - wyzwania i aspekty praktyczne, „Prawo Asekuracyjne” 2018, nr 3.

Ustawa o działalności ubezpieczeniowej i reasekuracyjnej. Komentarz, Szczepańska M., Wajda P. [red.], Wolters Kluwer, Warszawa 201 ?

Zarzadzanie ryzykiem bankowym, Iwanicz-Drozdowska M. [red.], Poltex, Warszawa 2017.

\section{Rekomendacje i stanowiska nadzorcze:}

Komunikat z dnia 20 sierpnia 2018 r. w sprawie roli i znaczenia realizacji przez zakłady ubezpieczeń i zakłady reasekuracji funkcji zgodności z przepisami, www. knf.gov.pl.

Stanowisko Komisji Nadzoru Finansowego z dnia 16 lutego 2016 r. w sprawie wymagań w zakresie systemu zarządzania funkcjonującego w zakładzie ubezpieczeń / reasekuracji, www. knf.gov.pl. Uchwała Komisji Nadzoru Finansowego nr 258/2011 z dnia 4 października 2011 r. w sprawie szczegółowych zasad funkcjonowania systemu zarządzania ryzykiem i systemu kontroli wewnętrznej oraz szczegółowych warunków szacowania przez banki kapitału wewnętrznego i dokonywania przeglądów procesu szacowania i utrzymywania kapitału wewnętrznego oraz zasad ustalania polityki zmiennych składników wynagrodzeń osób zajmujących stanowiska kierownicze w banku, www. knf.gov.pl.

Wytyczne Europejskiego Urzędu Nadzoru Ubezpieczeń i Pracowniczych Programów Emerytalnych (EIOPA) dotyczące zarządzania zakładem ubezpieczeń.

Zasady Ładu Korporacyjnego dla instytucji nadzorowanych, wydane przez Komisję Nadzoru Finansowego.

Międzynarodowe standardy dotyczące prowadzenia działalności ubezpieczeniowej i zasad nadzoru ubezpieczeniowego, wydane przez Międzynarodowe Stowarzyszenie Nadzorców Ubezpieczeniowych (IAIS).

Norma ISO 19600:2014.

Komisja Nadzoru Finansowego, Rekomendacja H dotycząca systemu kontroli wewnętrznej w bankach. Komisja Nadzoru Finansowego, Rekomendacje dotyczące systemu zarządzania produktem w zakładach ubezpieczeń. 


\section{The role of compliance function in compliance risk management in an insurance company in the context of the functioning and organization of this function in the structures of an insurance company}

The main purpose of this article is to try to determine the importance of the compliance function in the process of managing non-compliance risk in an insurance company through the prism of functioning and organization of this unit within the structures of an insurance company. The method used to achieve this objective is in the author's opinion, first and foremost, an assessment of the current regulatory environment in the context of its impact on the organization and operation of the compliance function in an insurance company. Considerations devoted to the compliance risk management process were also presented taking into account legal solutions applicable in banks.

Keywords: compliance, compliance function, compliance risk, compliance, regulations.

WOJCIECH PAŚ - absolwent Wydziału Prawa i Administracji Uniwersytetu Warszawskiego oraz podyplomowych studiów z zarządzania ryzkiem w instytucjach finansowych w Szkole Głównej Handlowej, ekspert w biurze Compliance w PZU SA i PZU Życie SA.

e-mail:w.pas0?@gmail.com 